\title{
EFFECTS OF ALTERNATIVE FISH SPECIES AMBLYPHARYNGODON MOLA FOR TRADITIONAL CARP POLYCULTURE IN NEPAL
}

\section{Basant Kumar Karn, Ranjana Gupta and Sunila Rai}

Journal of Institute of Science and Technology

Volume 22, Issue 2, January 2018

ISSN: 2469-9062 (print), 2467-9240 (e)

\section{Editors:}

Prof. Dr. Kumar Sapkota

Prof. Dr. Armila Rajbhandari

Assoc. Prof. Dr. Gopi Chandra Kaphle Mrs. Reshma Tuladhar

JIST, 22 (2): 92-102 (2018)

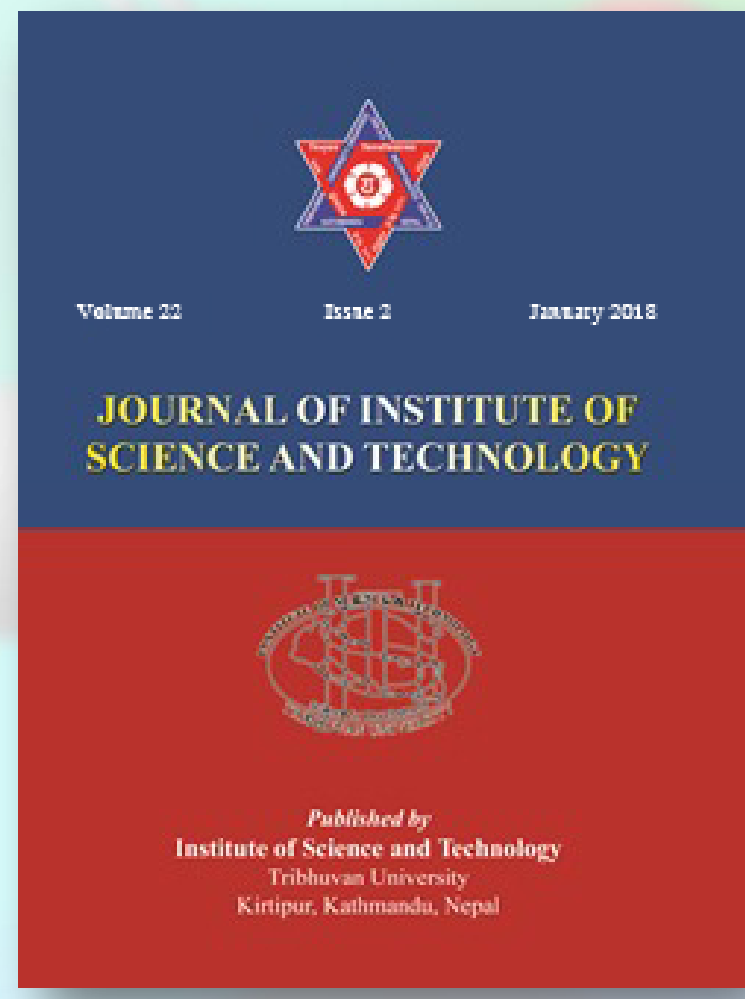

Published by:

Institute of Science and Technology

Tribhuvan University

Kirtipur, Kathmandu, Nepal 


\title{
EFFECTS OF ALTERNATIVE FISH SPECIES AMBLYPHARYNGODON MOLA FOR TRADITIONAL CARP POLYCULTURE IN NEPAL
}

\author{
Basant Kumar Karn ${ }^{1}$, Ranjana Gupta ${ }^{* 2}$ and Sunila Rai ${ }^{3}$ \\ ${ }^{I}$ Department of Zoology, Ram Swarup Ram Sagar Multiple Campus, Tribhuvan University, Janakpur, Nepal \\ ${ }^{2}$ Central Department of Zoology, Tribhuvan University, Kirtipur, Nepal \\ ${ }^{3}$ Department of Aquaculture, Agriculture and Forestry University, Rampur, Nepal \\ *Corresponding E-mail: drgupta.ohm@gmail.com
}

Received: 22 April, 2017; Revised: 5 October, 2017; Accepted: 6 November, 2017

\begin{abstract}
To increase the maximum productivity is prime aim in fish aquaculture from past few years. The increase in maximum standing crop of a pond depends upon the wider range of available foods in ecological niches from the selection of complementary species growing together. The present work was conducted in an attempt to identify the suitable fish species combinations among Hypophthalmichthys molitrix, Aristichthys nobilis, Ctenopharyngodon idella, Cyprinus carpio with the introduction of Amblypharyngodon mola in the prevalent method of fish polyculture system practiced in Nepal. The experiment was conducted for 120 days, in twelve $100 \mathrm{~m}^{2}$ earthen ponds which comprised the initial growing period of fish. As control, one pond was stocked with a species ratio usually employed in the country; H. molitrix (35\%), A. nobilis (10 $\%)$, L. rohita (15\%), C. mrigala (10\%), C. idella, (5\%) and C. carpio (25\%). Treatment 2 was stocked with the H. molitrix, A. nobilis, L. rohita and C. mrigala. Treatment 3 was stocked with the H. molitrix, A. nobilis, L. rohita, C. mrigala and $C$. idella and Treatment 4 was stocked with the H. molitrix, A. nobilis, $L$. rohita, C. mrigala and C. idella and C. carpio. Each treatment had three replicates. Carp fishes were stocked with stocking density $15000 \mathrm{ha}^{-1}$ in all treatments. A. mola was stocked @ $50000 \mathrm{ha}^{-1}$ in treatments, 2, 3 and 4. No significant correlation was found between the growth rate of fish species and the water quality parameters. The final weight of different species, in different treatments, showed statistical differences. Considering growth parameters, the best result was obtained in treatment 2. A complete exclusion of the $A$. mola in treatment 1 had no advantage over the other treatments; however, the combination of Hypophthalmichthys molitrix, Aristichthys nobilis, Labeo rohita and Cirrhinus mrigala allowed the introduction of A. mola, with positive effects. In addition, the introduction of A. mola in the polycultures tested had no effect over the other carp species.
\end{abstract}

Keywords: Small indigenous fish species, Phytoplankton, Polyculture, Carps, Growth performance.

\section{INTRODUCTION}

Fish polyculture is practiced aiming to increase productivity. Complementary species of fishes can increase the maximum standing crop of a pond by allowing a wider range of available foods and ecological niches (Da silva et al., 2006). Fisheries activities are split by policy guidelines into inland aquaculture and natural water fisheries. Aquaculture involves all activities where complete or partial control of the fish production cycle is undertaken (FAO, 2014). The long term goal for fisheries and aquaculture development is to enhance livelihoods through sustainable fisheries and aquaculture technology for food, employment and income (Rai et al., 2008). Fishes are considered auspicious and symbolize as sign of fertility, power and prosperity in Nepal (Gurung et $a l ., 2003)$. Fish is acceptable to every segment of the population, but still Nepal has a low per capita consumption compared to neighboring countries despite of the increasing trend of fish production (Rai et al., 2008). The per capita consumption of fish per gram per day was 5.39 in 2010/2011 (Environment Statistics of Nepal, 2013). The 
majority of rural and urban peoples have less access to the fishes in spite of increase in insufficient fish production. So the problem of fish consumption is concerned with the production of fish in national level. There is urgent need of changes in the existing method of fish farming practices as well as of natural water fisheries management that may be problem solving approach. The use of piscicides before stocking of carps in present fish farming system removes almost all indigenous fishes including catfishes and small indigenous fish species (SIS) which were also earlier called as weed fish. The small indigenous fish species (SIS) are generally considered to be those fishes which grow to be length of about $25 \mathrm{~cm}$ or 9 inches (Hossain \& Afroze, 1991; Felts et al., 1996). The early concept of food competition between large carp species and SIS may be major cause of removal of SIS without of scientific study in Nepalese context and condition of pond polyculture practice. Nepalese women and children suffer from malnutrition of animal source of protein and micronutrients; vitamin A, iron, calcium, phosphorus, zinc etc (MOPH, 2014). The present existing semi-intensive carp polyculture system in Nepal cannot promote to the household fish consumption rapidly. Present trend in fish polyculture system of Nepal shows once carp fingerlings are stocked in the ponds, farmers have to wait for income and family member fish consumption either one or more than one year, till their entire crop is not harvested for the sell purpose. They keep the family members unfed from the fishes and the farmers cannot get short time monetary return from the whole duration of fish culture period.

If Indigenous fish species and carp fishes are cultured together, farmers would have opportunity to harvest small indigenous fishes in short time of stocking. They can fed the family members with small indigenous fishes or will have option for selling them also before of carp as the cash crop. Hence, the semi intensive aquaculture system in which the carp and SIS can be grown together seems to be a new approach in the fish farming sector of Nepal. The carp SIS culture system is cost effective and it gives relatively high fish production per unit area, monetary return etc than the traditional semi intensive fish culture system (Roy, 2004). The carp-SIS fish culture practice may have great potential in rural aquaculture of Nepal. This experiment was basically designed therefore to investigate the suitable combination of carps which can be reared with alternative SIS species A. mola in ponds condition of Janakpur.

\section{MATERIALS AND METHOD}

\section{Experimental fish species and pond preparation}

The carp fishes like silver carp (Hypophthalmicthys molitrix), bighead carp (Aristychthys nobilis), grass carp (Ctenopharyngodon idella), common carp (Cyprinus carpio), rohu (Labeo rohita) and naini (Cirrhinus mrigala) and Mara (Amblypharyngodon mola) were used for the experimental fish. Prior to stocking, all the ponds were drained, dried and limed with powdered $\mathrm{CaCO}_{3}$ at a rate of $500 \mathrm{~kg}^{-}$ ${ }^{1}$. Ponds were filled up with water up to $1.0 \mathrm{~m}$ deep. Ponds were fertilized with semi-decomposed cattle dung, urea and DAP at the rate of 1000, 25 and 25 $\mathrm{kg} \mathrm{ha}^{-1}$ after one week of liming (Roy, 2004). Fish species were stocked after 7 days of the use of manuring and fertilizer. $\operatorname{Re}$ fertilization was adjusted in ponds on the basis of secchi disc reading @ $12.5 \mathrm{~kg}$ urea and $25 \mathrm{~kg}$ DAP ha ${ }^{-1}$.

\section{Fish stocking and post stocking management}

The silver carp (H. molitrix), bighead carp (A. nobilis), rohu ( $L$. rohita), naini (C. mrigala), grass carp $(C$. idella), common carp $(C$. carpio) were stocked @ 15000 fingerlings ha ${ }^{-1}$ and Mara (A. mola) @ $50000 \mathrm{ha}^{-1}$. The experiment was conducted in three treatments T2, T3, and T4 and a control (ctrl) T1 for experiment in CRBD (complete randomized block design) method. Three replications were allocated for each treatment of experiment.

The ponds for each treatment and control were allocated randomly. Three replications were allocated for each treatment as p3, p6, p8 for T1 treatment p2, $\mathrm{p} 9, \mathrm{p} 12$ for $\mathrm{T} 2$ treatment $\mathrm{p} 4, \mathrm{p} 5, \mathrm{p} 11$ for $\mathrm{T} 3$ treatment and p1, p7, p10 for T4 treatment. Details of carps and SIS stocking in the experiment is shown in table 1.

Out of six different species of carps; silver carp, bighead carp, rohu, naini, grass carp and common carp, only three different combinations of carp fishes were tested in the experiment as follows; treatment 1or control (T1- silver carp, bighead carp, rohu, naini, grass carp and common carp), treatment 2 (T2- silver carp, bighead carp, rohu, naini and mara), treatment 3 (T3- silver carp, bighead carp, rohu, naini, grass carp and mara) and treatment 4 (T4 - silver carp, bighead carp, rohu, naini, grass carp common carp and mara). The details of stocking weight of fingerlings of silver carp, bighead carp, rohu, naini, grass carp, common carp and mara is shown in table 2 . 
Table 1: Stocking density of carps and A. mola $\left(\mathrm{ha}^{-1}\right)$ in treatments of experiment.

\begin{tabular}{|l|l|l|l|l|}
\hline \multirow{2}{*}{ Fish species } & \multicolumn{4}{|c|}{ Treatments } \\
\cline { 2 - 5 } & \multicolumn{1}{|c|}{ T1(ctrl) } & \multicolumn{2}{c|}{ T2 } & \multicolumn{1}{c|}{ T3 } \\
\hline silver carp & 5200 & 6400 & 6000 & 5200 \\
\hline bighead carp & 1500 & 2600 & 2200 & 1500 \\
\hline rohu & 2300 & 3400 & 3000 & 2300 \\
\hline naini & 1500 & 2600 & 2300 & 1500 \\
\hline grass carp & 700 & 0 & 1500 & 700 \\
\hline common carp & 3800 & 0 & 0 & 3800 \\
\hline A. mola & 0 & 50000 & 50000 & 50000 \\
\hline
\end{tabular}

Supplementary food in the form of mustard oil cake and rice bran (1:2) ratio were provided to standing fishes of pond according to $5 \%$ their body weight. Fertilization with urea, DAP and cattle dung were reused at the rate of $12.5 \mathrm{~kg} \mathrm{ha}^{-1}, 12.5 \mathrm{~kg} \mathrm{ha}^{-1}$ and $375 \mathrm{~kg} \mathrm{ha}^{-1}$ to maintain natural food in the ponds, respectively according to the secchi disc reading (Roy, 2004). All experimental fishes were harvested by repeated netting and dewatering of the ponds using diesel pumps, the remained fishes were caught by hand picking to determine the yield of fish species. All the harvested fish species were washed, counted, weighed and measured separately to keep the record for assessment of survival rate and production. Net yield was determined by deducting stocked experimental fishes from harvested fishes. The following parameters were used to evaluate the growth of fishes:

Total Weight gain $(\mathrm{g})=$

Total final weight $(\mathrm{g})$ - Total initial weight $(\mathrm{g})$

Survival rate $(\%)=$

$$
\frac{\text { No.of fish harvested }}{\text { Initialno.of fishes stocked }} \times 100
$$

\section{Water quality analysis}

Monitoring of water quality parameters such as water temperature, transparency, dissolved Oxygen (DO), $\mathrm{pH}$, total alkalinity and $\mathrm{CO}_{2}$ was performed every fortnight during the experimental period. Temperature and dissolved Oxygen (DO) were measured by a digital DO meter (YSI, model 58), transparency was measured by using a Secchi disc and $\mathrm{pH}$ by a $\mathrm{pH}$ meter (Hanna microelectronics), total alkalinity and $\mathrm{CO}_{2}$ was measured by acid titration method following (Stirling,1985). Temperature $\left({ }^{0} \mathrm{C}\right), \mathrm{pH}$, transparency $(\mathrm{cm})$ and DO (mg L L ${ }^{-1}$ ) were measured directly from the experimental ponds between 0800 and $0900 \mathrm{hrs}$ and other parameters were measured at Water Quality Laboratory of the Fisheries Development and Training Centre and laboratory of Ram Swarup Ram Sagar Multiple Campus, Janakpur.

\section{Economic Analysis}

Economic analyses of different treatments were performed on the basis of the expenditure incurred and the total return from the selling price of freshwater carp fishes and SIS. The economic analysis (benefit cost ratio) was carried out on the basis of record of inputs (Food, fertilizer, lime, manure, fingerlings of carps and SIS, labor cost, etc.) and outputs (fish sold, fish consumed, etc) were used during the treatments of experiments. All records of investment and return in Neplese Rupees (N Rs) were kept in the record for further analysis, although the price of carps and SIS depended on their size in local market. The net benefit was calculated by using the following formula:

Net benefit $=$ total income - total variable cost

\section{RESULTS}

Growth and production assessment among carp combinations with SIS

The growth and production performance of carp species; silver carp, bighead carp, rohu, naini, grass carp and common carp with A. mola in all treatments, T1 (ctrl) and T2, T3, T4 are shown in table 2. Net fish production $\mathrm{kg} \mathrm{ha} \mathrm{hr}^{-1}$ of experiment is shown in table 3. Net fish production $\mathrm{ha}^{-1} \mathrm{yr}^{-1}$ was found in the highest quantity in combination of silver carp, bighead carp, rohu, naini with mara of treatment T2 $(4559.4 \mathrm{~kg}$ $\left.\mathrm{ha}^{-1} \mathrm{yr}^{-1}\right)$. The lowest fish production $3184.9 \mathrm{~kg} \mathrm{ha}^{-}$ ${ }^{1} \mathrm{yr}^{-1}$ was found in combination of carps species silver carp, bighead carp, rohu, naini, grass carp and common carp of treatment T1(ctrl). 
Table 2: Growth \& production performance of carps \& SIS of experiment (Mean \pm S.E).

\begin{tabular}{|c|c|c|c|c|}
\hline \multirow{2}{*}{ Parameters } & \multicolumn{4}{|c|}{ Treatments } \\
\hline & $\mathbf{T 1}$ & $\mathbf{T 2}$ & T3 & $\mathbf{T 4}$ \\
\hline \multicolumn{5}{|l|}{ Silver carp } \\
\hline Initial mean wt.(g fish $\left.{ }^{-1}\right)$ & $9.2 \pm 0.48$ & $9.2 \pm 0.33$ & $9.2 \pm 0.48$ & $9.2 \pm 0.24$ \\
\hline Initial total wt. $\left(\mathrm{kg}\right.$ pond $\left.{ }^{-1}\right)$ & $0.588 \pm 0.01$ & $0.588 \pm 0.02$ & $0.552 \pm 0.01$ & $0.478 \pm 0.01$ \\
\hline Final harvesting wt. $\left(\mathrm{g}\right.$ fish $\left.^{-1}\right)$ & $110 \pm 2.35$ & $134 \pm 0.81$ & $132.3 \pm 1.18$ & $129 \pm 1.69$ \\
\hline Final total wt.(kg pond $\left.{ }^{-1}\right)$ & $5.2 \pm 0.11$ & $7.8 \pm 0.01$ & $7.0 \pm 0.06$ & $6.1 \pm 0.08$ \\
\hline Daily weight gain $\left(\mathrm{g}^{-1} \mathrm{fish}^{-1} \mathrm{day}^{-1}\right)$ & $0.8 \pm 0.01$ & $1.0 \pm 0$ & $1.0 \pm 0$ & $0.9 \pm 0.01$ \\
\hline Net mean fish yield $\left(\mathrm{kg}\right.$ pond $\left.{ }^{-1}\right)$ & $4.7 \pm 0.11$ & $7.2 \pm 0.01$ & $6.4 \pm 0.05$ & $5.6 \pm 0.08$ \\
\hline Survival ( \% ) & $91.0 \pm 1.04$ & $93.0 \pm 1.42$ & $88.3 \pm 0.05$ & $91.6 \pm 0.52$ \\
\hline Net fish yield $\left(\mathrm{kg} \mathrm{ha}^{-1} \mathrm{yr}^{-1}\right)$ & $1438.1 \pm 0.11^{\mathrm{b}}$ & $2198.2 \pm 0.01^{\mathrm{a}}$ & $1965.2 \pm 0.05^{\mathrm{ab}}$ & $1724.6 \pm 0.08^{\mathrm{ab}}$ \\
\hline \multicolumn{5}{|l|}{ Bighead carp } \\
\hline Initial mean wt.(g fish $\left.{ }^{-1}\right)$ & $8.7 \pm 0.21$ & $8.7 \pm 0.33$ & $8.7 \pm 0.16$ & $8.7 \pm 0.21$ \\
\hline Initial total wt. $\left(\mathrm{kg}\right.$ pond $\left.{ }^{-1}\right)$ & $0.13 \pm 0.01$ & $0.23 \pm 0.01$ & $0.19 \pm 0.01$ & $0.13 \pm 0.01$ \\
\hline Final harvesting wt.(g fish $\left.{ }^{-1}\right)$ & $86 \pm 0.81$ & $89 \pm 1.69$ & $85.6 \pm 1.9$ & $85 \pm 1.41$ \\
\hline Final total wt.(kg pond $\left.{ }^{-1}\right)$ & $1.1 \pm 0.02$ & $1.9 \pm 0.05$ & $1.5 \pm 0.01$ & $0.935 \pm 0.01$ \\
\hline Daily weight gain $\left(\mathrm{g}^{-1}\right.$ fish $^{-1}$ day $\left.^{-1}\right)$ & $0.64 \pm 0.0$ & $0.66 \pm 0.01$ & $0.64 \pm 0.01$ & $0.63 \pm 0.01$ \\
\hline Net mean fish yield $\left(\mathrm{kg}\right.$ pond $\left.{ }^{-1}\right)$ & $0.959 \pm 0.03$ & $1.6 \pm 0.06$ & $1.3 \pm 0.01$ & $0.8 \pm 0.01$ \\
\hline Survival ( \% ) & $84.4 \pm 1.81$ & $84.3 \pm 1.99$ & $80.3 \pm 1.50$ & $73.3 \pm 3.14$ \\
\hline Net fish yield $\left(\mathrm{kg} \mathrm{ha}^{-1} \mathrm{yr}^{-1}\right)$ & $291.6 \pm 0.03$ & $514.1 \pm 0.06$ & $389.3 \pm 0.01$ & $244.5 \pm 0.01$ \\
\hline \multicolumn{5}{|l|}{ Rohu } \\
\hline Initial mean wt.(g fish $\left.{ }^{-1}\right)$ & $8.0 \pm 0.62$ & $10 \pm 0.62$ & $10.0 \pm 0.23$ & $8.0 \pm 0.62$ \\
\hline Initial total wt. $\left(\mathrm{kg}\right.$ pond $\left.{ }^{-1}\right)$ & $0.23 \pm 0.00$ & $0.34 \pm 0.00$ & $0.30 \pm 0.02$ & $0.23 \pm 0.05$ \\
\hline Final harvesting wt.(g fish $\left.{ }^{-1}\right)$ & $71.6 \pm 1.36$ & $86.6 \pm 1.9$ & $76.6 \pm 1.36$ & $76 \pm 0.81$ \\
\hline Final total wt.(kg pond $\left.{ }^{-1}\right)$ & $1.4 \pm 0.04$ & $2.5 \pm 0.05$ & $1.8 \pm 0.04$ & $1.3 \pm 0$ \\
\hline Daily weight gain $\left(\mathrm{g}^{-1}\right.$ fish $^{-1}$ day $\left.^{-1}\right)$ & $0.51 \pm 0.01$ & $0.63 \pm 0.01$ & $0.55 \pm 0.01$ & $0.54 \pm 0$ \\
\hline Net mean fish yield $\left(\mathrm{kg}\right.$ pond $\left.^{-1}\right)$ & $1.2 \pm 0.04$ & $2.2 \pm 0.05$ & $1.5 \pm 0.04$ & $1.1 \pm 0$ \\
\hline Survival ( \% ) & $86.9 \pm 2.05$ & $84.8 \pm 1.42$ & $82.6 \pm 1.08$ & $78.2 \pm 4.09$ \\
\hline Net fish yield $\left(\mathrm{kg} \mathrm{ha}^{-1} \mathrm{yr}^{-1}\right)$ & $365.9 \pm 0.04$ & $702.6 \pm 0.05^{\mathrm{a}}$ & $483.9 \pm 0.04^{\mathrm{ab}}$ & $338.2 \pm 0^{\mathrm{b}}$ \\
\hline \multicolumn{5}{|l|}{ Naini } \\
\hline Initial mean wt.(g fish $\left.{ }^{-1}\right)$ & $9.0 \pm 0.28$ & $9.0 \pm 0.16$ & $9.0 \pm 0.16$ & $9.0 \pm 0.28$ \\
\hline Initial total wt. $\left(\mathrm{kg}\right.$ pond $\left.{ }^{-1}\right)$ & $0.135 \pm 0.00$ & $0.542 \pm 0.08$ & $0.207 \pm 0.00$ & $0.135 \pm 0.00$ \\
\hline Final harvesting wt.(g fish $\left.{ }^{-1}\right)$ & $72.3 \pm 1.18$ & $86.6 \pm 1.36$ & $82.3 \pm 1.18$ & $77 \pm 1.24$ \\
\hline Final total wt. $\left(\mathrm{kg}\right.$ pond $\left.{ }^{-1}\right)$ & $0.844 \pm 0.03$ & $1.9 \pm 0$ & $1.5 \pm 0.01$ & $0.924 \pm 0.01$ \\
\hline Daily weight gain $\left(\mathrm{g}^{-1} \mathrm{fish}^{-1} \mathrm{day}^{-1}\right)$ & $0.52 \pm 0$ & $0.64 \pm 0.01$ & $0.61 \pm 0.01$ & $0.56 \pm 0$ \\
\hline Net mean fish yield $\left(\mathrm{kg}\right.$ pond $\left.{ }^{-1}\right)$ & $0.709 \pm 0.02$ & $1.7 \pm 0$ & $1.3 \pm 0.01$ & $0.789 \pm 0.01$ \\
\hline Survival ( \% ) & $79.2 \pm 1.92$ & $79.2 \pm 1.92$ & $84.3 \pm 1.16$ & $80 \pm 1.54$ \\
\hline Net fish yield $\left(\mathrm{kg} \mathrm{ha}^{-1} \mathrm{yr}^{-1}\right)$ & $215.6 \pm 0.02^{\mathrm{b}}$ & $525.9 \pm 0^{\mathrm{a}}$ & $420.9 \pm 0.01^{\mathrm{ab}}$ & $239.9 \pm 0.01$ \\
\hline
\end{tabular}


Contd. Table 2: Growth \& production performance of carps \& SIS of experiment.

\begin{tabular}{|c|c|c|c|c|}
\hline \multirow{2}{*}{ Parameters } & \multicolumn{4}{|c|}{ Treatments } \\
\hline & T1 & $\mathbf{T 2}$ & $\mathbf{T 3}$ & $\mathbf{T 4}$ \\
\hline \multicolumn{5}{|l|}{ G. carp } \\
\hline Initial mean wt.(g fish $\left.{ }^{-1}\right)$ & $8.5 \pm 0.24$ & 0 & $8.5 \pm 0.24$ & $8.5 \pm 0.24$ \\
\hline Initial total wt. $\left(\mathrm{kg}_{\text {pond }}{ }^{-1}\right)$ & $0.059 \pm 0.00$ & 0 & $0.294 \pm 0.04$ & $0.14 \pm 0.02$ \\
\hline Final harvesting wt. $\left(\mathrm{g}\right.$ fish $\left.^{-1}\right)$ & $77.6 \pm 1.18$ & 0 & $76.6 \pm 1.36$ & $77.6 \pm 1.18$ \\
\hline Final total wt. $\left(\mathrm{kg}\right.$ pond $\left.\mathrm{d}^{-1}\right)$ & $0.441 \pm 0.02$ & 0 & $0.971 \pm 0.03$ & $0.415 \pm 0.02$ \\
\hline Daily weight gain $\left(\mathrm{g}^{-1}\right.$ fish $^{-1}$ day $\left.^{-1}\right)$ & $0.57 \pm 0.01$ & 0 & $0.56 \pm 0.02$ & $0.57 \pm 0.01$ \\
\hline Net mean fish yield $\left(\mathrm{kg}\right.$ pond $\left.^{-1}\right)$ & $0.381 \pm 0.01$ & 0 & $0.844 \pm 0.03$ & $0.355 \pm 0.02$ \\
\hline Survival ( \% ) & $80.9 \pm 3.8$ & 0 & $84.2 \pm 1.72$ & $73.3 \pm 5.4$ \\
\hline Net fish yield $\left(\mathrm{kg} \mathrm{ha}^{-1} \mathrm{yr}^{-1}\right)$ & $115.8 \pm 0.01$ & 0 & $256.7 \pm 0.03$ & $107.9 \pm 0.02$ \\
\hline \multicolumn{5}{|l|}{ C. carp } \\
\hline Initial mean wt.(g fish $\left.{ }^{-1}\right)$ & $9.5 \pm 0.16$ & 0 & 0 & $9.5 \pm 0.14$ \\
\hline Initial total wt. $\left(\mathrm{kg}\right.$ pond $\left.{ }^{-1}\right)$ & $0.361 \pm 0.00$ & 0 & 0 & $0.834 \pm 0.13$ \\
\hline Final harvesting wt. $\left(\mathrm{g} \mathrm{fish}^{-1}\right)$ & $87.3 \pm 1.18$ & 0 & 0 & $100.6 \pm 0.54$ \\
\hline Final total wt. $\left(\mathrm{kg}\right.$ pond $\left.{ }^{-1}\right)$ & $2.8 \pm 0.04$ & 0 & 0 & $3.0 \pm 0.01$ \\
\hline Daily weight gain $\left(\mathrm{g}^{-1}\right.$ fish $^{-1}$ day $\left.^{-1}\right)$ & $0.64 \pm 0.01$ & 0 & 0 & $0.75 \pm 0.01$ \\
\hline Net mean fish yield $\left(\mathrm{kg}\right.$ pond $\left.^{-1}\right)$ & $2.4 \pm 0.04$ & 0 & 0 & $2.7 \pm 0.01$ \\
\hline Survival ( \% ) & $86.8 \pm 3.72$ & 0 & 0 & $80.7 \pm 1.42$ \\
\hline Net fish yield $\left(\mathrm{kg} \mathrm{ha}^{-1} \mathrm{yr}^{-1}\right)$ & $757.6 \pm 0.04$ & 0 & 0 & $828.8 \pm 0.01$ \\
\hline \multicolumn{5}{|l|}{ A. mola } \\
\hline Initial mean wt.(g fish $\left.{ }^{-1}\right)$ & 0 & $1.2 \pm 0.09$ & $1.2 \pm 0.12$ & $1.2 \pm 0.09$ \\
\hline Initial total wt. $\left(\mathrm{kg}\right.$ pond $\left.{ }^{-1}\right)$ & 0 & $1.3 \pm 0.21$ & $1.3 \pm 0.22$ & $1.3 \pm 0.21$ \\
\hline Final harvesting wt. $\left(\mathrm{g} \mathrm{fish}^{-1}\right)$ & 0 & $3.0 \pm 0.05$ & $3.0 \pm 0.0$ & $3.0 \pm 0$ \\
\hline Final total wt. $\left(\mathrm{kg}\right.$ pond $\left.{ }^{-1}\right)$ & 0 & $2.6 \pm 0.06$ & $2.4 \pm 0.05$ & $2.4 \pm 0.01$ \\
\hline Daily weight gain $\left(\mathrm{g}^{-1} \mathrm{fish}^{-1} \mathrm{day}^{-1}\right)$ & 0 & $0.01 \pm 0$ & $0.01 \pm 0$ & $0.01 \pm 0$ \\
\hline Net mean fish yield $\left(\mathrm{kg}\right.$ pond $\left.{ }^{-1}\right)$ & 0 & $2.0 \pm 0$ & $1.9 \pm 0.1$ & $1.8 \pm 0.09$ \\
\hline Net fish yield $\left(\mathrm{kg} \mathrm{ha}^{-1} \mathrm{yr}^{-1}\right)$ & 0 & $618.6 \pm 0$ & $606.2 \pm 0.1$ & $566.6 \pm 0.09$ \\
\hline
\end{tabular}

Different superscript letters in the same row are significantly different $(P<0.05)$ according to one way ANOVA with Tukey's test.

Table 3: Treatment wise Net fish production $\mathrm{kg} \mathrm{ha}^{-1} \mathrm{yr}^{-1}$ of the experiment.

\begin{tabular}{lllll}
\hline \multicolumn{1}{c}{ Fish sps. } & \multicolumn{1}{c}{ T1 } & \multicolumn{1}{c}{ T2 } & \multicolumn{1}{c}{ T3 } & \multicolumn{1}{c}{ T4 } \\
\hline silver carp & $1438.1 \pm 0.11$ & $2198.2 \pm 0.01$ & $1965.2 \pm 0.05$ & $1724.6 \pm 0.08$ \\
bighead carp & $291.6 \pm 0.03$ & $514.0 \pm 0.06$ & $389.3 \pm 0.01$ & $244.5 \pm 0.01$ \\
rohu & $365.9 \pm 0.04$ & $702.6 \pm 0.05$ & $483.9 \pm 0.04$ & $338.2 \pm 0$ \\
naini & $215.6 \pm 0.02$ & $525.9 \pm 0$ & $420.9 \pm 0.01$ & $239.9 \pm 0.01$ \\
grass carp & $115.8 \pm 0.01$ & $0.0 \pm 0$ & $256.7 \pm 0.03$ & $107.9 \pm 0.02$ \\
common carp & $757.6 \pm 0.04$ & $0.0 \pm 0$ & & $828.8 \pm 0.01$ \\
A. mola & $0.0 \pm 0$ & $618.6 \pm 0$ & $606.2 \pm 0.1$ & $566.6 \pm 0.09$ \\
\hline Net total prod $^{\mathrm{n}}$ & 3184.9 & 4559.4 & 4122.4 & 4050.8 \\
\hline
\end{tabular}

Different superscript letters in the same row are significantly different $(P<0.05)$ according to one way ANOVA with Tukey's test. 
Benefit-cost analysis of carp fishes combination with SIS

The financial characteristics of different treatments are presented in Table number 4 and 5 . The major and also variable input costs were mainly due to experimental carps fingerlings, supplemental feeds, lime and inorganic fertilizers. The net benefit was highest in treatment T2 $(2601.0 \pm 31.31$ rupees pond $\left.{ }^{-1}\right)$ followed by treatments T4 $(2453.23 \pm 44.61$ rupees pond $\left.{ }^{-1}\right)$, T3 $\left(2410.0 \pm 1043.2\right.$ rupees pond $\left.^{-1}\right)$ and T1 $\left(1660.34 \pm 17.75\right.$ rupees pond $\left.{ }^{-1}\right)$. Net benefit was the highest $352486.6 \pm 31.31$ rupees $\mathrm{ha}^{-1} \mathrm{yr}^{-1}$ in treatment $\mathrm{T} 2$ and the lowest production was $122965.5 \pm 17.75$ rupees $\mathrm{ha}^{-1} \mathrm{yr}^{-1}$. Treatments that included addition of $A$. mola gave better production as well as financial return than the carps reared without of A.mola (treatment T1) but the best financial return obtained from $\mathrm{T} 2$ treatment suggests, suitable combination of carps with A.mola is silver carp, bighead carp, rohu and naini.

Table 4: Gross return value of different treatments $\left(\right.$ pond $\left.^{-1}\right) 120$ days.

\begin{tabular}{llllllll}
\hline \multicolumn{7}{c}{ Treatments } \\
\hline & T1 & & T2 & & T3 & & T4 \\
\hline ponds & $\begin{array}{l}\text { Rupees } \\
\text { (NRs) }\end{array}$ & ponds & $\begin{array}{l}\text { Rupees } \\
\text { (NRs) }\end{array}$ & ponds & $\begin{array}{l}\text { Rupees } \\
\text { (NRs) }\end{array}$ & ponds & $\begin{array}{l}\text { Rupees } \\
\text { (NRs) }\end{array}$ \\
\hline P1 & 1642.3 & P3 & 2672.872 & P2 & 2470.272 & P4 & 2362.22 \\
P7 & 1703.6 & P6 & 2588.484 & P9 & 2324.892 & P5 & 2446.372 \\
P10 & 1635.07 & P8 & 2541.81 & P12 & 2434.898 & P11 & 2551.112 \\
\hline Mean \pm SE & $1660.34 \pm 17.75$ & Mean \pm SE & $2601.05 \pm 31.31$ & Mean \pm SE & $2410.02 \pm 35.74$ & Mean \pm SE & $2453.23 \pm 44.61$ \\
\hline
\end{tabular}

Table 5: Gross margin analysis of different treatments pond ${ }^{-1} \& \mathrm{ha}^{-1} \mathrm{yr}^{-1}$.

\begin{tabular}{|c|c|c|c|c|}
\hline \multirow{2}{*}{ Parameters } & \multicolumn{4}{|c|}{ Treatments } \\
\hline & $\mathbf{T 1}$ & $\mathbf{T} 2$ & T3 & $\mathbf{T 4}$ \\
\hline Outputs & $1660.34 \pm 17.75$ & $2601.05 \pm 31.31$ & $2410.02 \pm 35.74$ & $2453.23 \pm 44.61$ \\
\hline Inputs & $1256.07 \pm 0.04$ & $1442.19 \pm 0.06$ & $1426.41 \pm 0.30$ & $1510.25 \pm 0.29$ \\
\hline Gross margin pond $^{-1}$ & $404.27 \pm 17.75$ & $1158.86 \pm 31.31$ & $983.61 \pm 35.74$ & $942.98 \pm 44.61$ \\
\hline Gross margin $\mathrm{ha}^{-1} \mathrm{yr}^{-1}$ & $122965.5 \pm 17.75^{\mathrm{b}}$ & $352486.6 \pm 31.31^{\mathrm{a}}$ & $299181.4 \pm 35.74^{\mathrm{ab}}$ & $286823.1 \pm 44.61^{\mathrm{ab}}$ \\
\hline
\end{tabular}

Different superscript letters in the same row are significantly different $(P<0.05)$ according to one way ANOVA with Tukey's test.

\section{Water quality parameter}

The result of water quality parameters are summarized in table 6 .

\section{DISCUSSION}

\section{Growth and production performance of carps} and SIS

Three different combinations of carp species in treatment $\mathrm{T} 2$, treatment $\mathrm{T} 3$, and treatment $\mathrm{T} 4$ stocked with $A$. mola showed variation in growth and production of individual type of carp species treatment wise. Growth of silver carp was the highest in $\mathrm{T} 2$ treatment among all. The competition for food did not occur between silver carp and $A$. mola most probably sharing into different feeding niche. The addition of A. mola and/or Puntius sarana fish in the ponds did not affect the growth of silver and common carps (Kadir et al., 2007). In the present study there were no significant differences $(p>0.05)$ in individual harvesting weight of silver carp, indicating that silver carp production was not affected by the introduction of A. mola. Roy (2004) also reported that silver carp production was not affected by the presence or absence of $A$. mola in carp-mola polyculture system. Growth of bighead (zooplankton feeder) carp was the highest in T2 treatment among all. The growth of bighead carp was lower than the growth of silver carp in all treatments that might be due to the inter specific food competition between bighead carp and A. mola. Roy (2004) reported that 
production of catla (zooplankton feeder) was higher in presence of grass carp and in absence of silver carp in his study on carp-SIS polyculture system. The addition of A.mola or puntius sarana in fish ponds affected rohu and catla's growth but did not affect the growth of common carp and silver carp. The addition of $A$. mola reduced catla's production performance by $20-24 \%$ (Kadir et al., 2007). There were no significant differences $(p>0.05)$ in harvesting weight survival, total yield and net yield of bighead carp among treatments. Production of rohu was lower in present study in presence of both higher stocking densities of silver carp and A. mola respectively. This might be due to the inter specific competition between rohu and these two species. Roy (2004) reported lower growth of rohu in higher stocking densities of $A$. mola. Kohinoor \& Wahab (1998) also found that A. mola competes for food and space with rohu. The growth of naini and rohu in all treatments were less than silver carp perhaps due to the low stocking density and the slow growth rate of these fishes than the silver carp. Production of naini in this study was high in presence of $A$. mola. Presence of silver carp increased production of mrigal in an experiment conducted by Roy (2004).

Table 6: Mean values $( \pm \mathrm{SE})$ and water quality parameters.

\begin{tabular}{lllll}
\hline \multirow{2}{*}{ parameters } & \multicolumn{4}{c}{ Treatments } \\
\cline { 2 - 5 } & \multicolumn{1}{c}{ T1 } & \multicolumn{1}{c}{ T2 } & \multicolumn{1}{c}{ T3 } \\
\hline \multirow{2}{*}{ Temperature $\left({ }^{0} \mathrm{C}\right)$} & $28.4 \pm 0.37$ & $28.5 \pm 0.41$ & $28.5 \pm 0.43$ & $28.2 \pm 0.41$ \\
& $(27.2-32.5)$ & $(27.2-32.5)$ & $(27.1-33.2)$ & $(28.2-33.5)$ \\
Transparency $(\mathrm{cm})$ & $22.7 \pm 1.19$ & $20.3 \pm 1.40$ & $25.9 \pm 1.72$ & $21.3 \pm 1.21$ \\
& $(16.0-32.0)^{\mathrm{ab}}$ & $(24.0-40.0)^{\mathrm{ab}}$ & $(16.0-35.0)^{\mathrm{b}}$ & $(20.0-40.0)^{\mathrm{a}}$ \\
DO $\left(\mathrm{mg} \mathrm{L}^{-1}\right)$ & $5.4 \pm 0.21$ & $5.4 \pm 0.24$ & $5.4 \pm 0.23$ & $5.5 \pm 0.22$ \\
& $(4.1-8.5)$ & $(4.2-10.1)$ & $(4.6-10.1)$ & $(4.6-10.2)$ \\
pH & $7.4 \pm 0.11$ & $7.4 \pm 0.07$ & $7.4 \pm 0.89$ & $7.4 \pm 2.73$ \\
& $(7.7-8.5)$ & $(7.7-8.5)$ & $(7.7-8.5)$ & $(7.7-8.5)$ \\
Total Alkalinity $\left(\mathrm{mg} \mathrm{L}^{-1}\right)$ & $95.4 \pm 4.71$ & $91.1 \pm 3.66$ & $90.0 \pm 3.46$ & $92.2 \pm 4.19$ \\
& $(90.0-150)^{\mathrm{a}}$ & $(84.0-146)^{\mathrm{ab}}$ & $(76.0-140)^{\mathrm{b}}$ & $(89.0-152)^{\mathrm{ab}}$ \\
$\mathrm{CO}_{2}\left(\mathrm{mg} \mathrm{L}^{-1}\right)$ & $12.7 \pm 0.35$ & $13.0 \pm 0.35$ & $12.2 \pm 0.28$ & $12.2 \pm 0.30$ \\
& $(10.5-16.4)$ & $(10.5-16.2)$ & $(10.6-16.6)$ & $(10.5=16.4)$ \\
\hline
\end{tabular}

Different superscript letters in the same row are significantly different $(P<0.05)$ according to one way ANOVA with Tukey's test.

Milstein (1992) also reported such synergistic effect between silver carp and common carp. Grass carp growth was high at high stocking density of both silver carp and A. mola. Survival was the highest where both silver carp and $A$. mola were stocked in the treatment. Grass carp has antagonistic effect on more than one species in carp polyculture system. Roy (2004) found that grass carp production was not affected by the presence or absence of silver carp, but it performed better growth and production in presence of $A$. mola. The growth and production of common carp was high in combination with $A$. mola in T4 treatment of this experiment. Alim et al. (2005) reported that presence of A. mola had increased the growth parameter of common carp. These effects are explained and discussed considering fish interactions through the food web (Kadir et al., 2007). Roy (2004) stated that growth of A. mola was better with grass carp combination along with other carps reared together than the silver carp combination with other carps. The highest net yield of carps (4559.4 $\mathrm{kg} \mathrm{ha}^{-1} \mathrm{yr}^{-1}$ ) was found in $\mathrm{T} 2$, it may be due to of pond's food proper utilization, suitable water quality condition, and high abundance of planktons in pond water, consumption and conversion of artificial food and fish interactions through the food web. Paul (1998) and Hossain et al. (2006) recorded high yield of silver carp with 
the low production of zooplankton feeder species. The present finding of high yield of silver carp in carp SIS culture experiment satisfy with Paul (1998) and Hossain et al. (2006). The gross production of fishes (4559.4 $\left.\mathrm{kg} \mathrm{ha} \mathrm{hr}^{-1}\right)$ of present study is higher than that reported by Miah \& Siddique (1992), Mazid et al. (1997) and Rahman (2006). The gross production of carp fishes of present experiment was lower $(6767 \mathrm{~kg}$ $\mathrm{ha}^{-1} \mathrm{yr}^{-1}$ ) than those reported by Wahab et al. (1995). Lakshmanan et al. (1971) obtained the production of carp fishes $4209 \mathrm{~kg} \mathrm{ha}^{-1} \mathrm{yr}^{-1}$ from semi intensive fish culture method which is more or less similar to the gross production of carp fishes in the present study. The present finding is similar with the result obtained by Kunda et al. (2008). The gross yield of carps species under the combination of; silver carp, bighead carp, rohu and mrigala gave the better production with $A$. mola in the treatment $\mathrm{T} 2$ which was significantly ( $p>0.05$ ) higher than T3 and T4. It was the indication of suitable combination of carp species silver carp, bighead carp, rohu and mrigala in spite of silver carp, bighead carp, rohu, mrigala, grass carp and common carp for the rearing with SIS species $A$. mola in semi intensive pond aquaculture. A. mola didn't affect the growth of carps species silver carp, bighead carp, rohu and mrigala in treatment $\mathrm{T} 2$ because food efficiency of all niches of pond was properly utilized by the carps and A. mola species and there were also no overlapping of food niches among them.

\section{Gross margin analysis}

Gross margin analysis showed that all treatments were profitable. Gross margin was higher in combination of silver carp, bighead carp, rohu and mrigala with A.mola in treatment T2 than that in the silver carp, bighead carp, rohu, mrigala, grass carp and common carp treatment probably due to low return value from the selling of grass carp, common carp and less quantity of A.mola for the sale. Based on fish production and economic return, the silver carp, bighead carp, rohu and mrigala with A.mola treatment seemed better for the resource-poor farmers since the A.mola is self recruiting species so it's partial harvesting in the ponds with supplemental feed gave high fish production as high as in the only carps treatment. Using on-farm by-products like rice bran and mustard oil cake not only enhances the fish production but also makes venture cost effective. The financial return was Rs $115886 \mathrm{~N}$
$\mathrm{Rs} \mathrm{ha}^{-1}$ in 120 days, which is higher than the net benefit reported by Roy (2004) 94,925, 88,330 and 68,270 Tk. per hectare per 7 months for only carps, carps plus A.mola and carps plus chela polyculture systems, respectively. The high financial return (202800.5 ha ${ }^{-1}$ per seven month) of present study was probably due to increase in production of carp from inclusion of rapidly growing bighead carp in spite of Catla catla and A.mola in the present experiment and the price value of total variable cost, revenue in local market.

\section{Water quality parameters}

The water quality is a paramount factor in ecosystem productivity of fish ponds. The feeding intensity of fishes, their growth, metabolism, reproduction etc. are regulated in the pond ecosystem by water temperature. All water quality parameters remained in the normal range for carp A.mola culture. There were no significant effects on addition of fishes, artificial feed and fertilizer on water quality. The water temperature remained from $27.1^{\circ} \mathrm{C}$ to $33.5^{\circ} \mathrm{C}$ in the experimental ponds which was suitable for fish culture. It agrees with the findings of Paul (1998) who recorded water temperature between $26.7-33.7^{\circ} \mathrm{C}$ of carp polyculture with silver carp and A.mola fish rearing ponds at the Bangladesh Agricultural University Campus, Mymensingh. Wahab et al. (1996) recorded water temperature between 28.5 to $31.3^{\circ} \mathrm{C}$ in the ponds used for fertilization experiment. Kohinoor (2000) also recorded water temperature between 18.5 to $32.9^{\circ} \mathrm{C}$ in the experimental ponds. The water transparency is generally expressed as the level of productivity of water body and it also indicates the presence or absence of natural fish food organisms. The transparency of pond water recorded from 16.0 to $40.0 \mathrm{~cm}$ in the present study indicates that the ponds were productive and a little bit turbid. Boyd (1979) recommended the transparency ranged from 15 to $40 \mathrm{~cm}$ is appropriate for fish culture. The less transparent or increased turbidity of pond water that appeared might be due to planktonic organisms and presence of common carp which is reported to be the most common natural reason for turbidity. Wahab et al. (2002) reported that common carp damages pond embankments by searching for food or burrowing to build nests which results reduced transparency. The transparency observed in experiment signifies that the culture ponds were somewhat suitable for fish culture though it exceeded the preferred range due to biological interaction of common carp. The 
concentration of dissolved oxygen (DO) in the experimental ponds had generally fluctuated from the range of $4.1 \mathrm{mg} \mathrm{L}^{-1}$ to $10.1 \mathrm{mg} \mathrm{L}^{-1}$. Banerjea (1967) reported that dissolved oxygen ranging from 5 to $7 \mathrm{mg} \mathrm{L}^{-1}$ was good for fish culture. Ophenheimer et al. (1978) and Wahab et al. (1995) recorded the dissolved oxygen values from 3.1 to 7.5 and 2.2 to $7.1 \mathrm{mg} \mathrm{L}^{-1}$, respectively. Roy (2004) recorded 3.6 to $7.6 \mathrm{mg} \mathrm{L}^{-1}$ dissolved oxygen in carp- A.mola polyculture ponds in rural farmer's ponds. The upper limit of dissolved oxygen reading in present study was more than Ophenheimer et al. (1978) and Wahab et al. (1995) that might be due to the increased activity of phytoplanktons in pond water. The $\mathrm{pH}$ is an important factor in a fish pond and also called as the productivity index of a water body. An acidic $\mathrm{pH}$ of water reduces the growth, metabolism and other physiological activities of fishes (Swingle, 1967). The $\mathrm{pH}$ of pond water was between 7.7 to 8.5 . It was suitable for fish culture according to Swingle (1967) who suggested the suitable $\mathrm{pH}$ of pond water for fish culture lie between 6.5 to 9.0. Kohinoor (1998) recorded the $\mathrm{pH}$ between 7.1 to 7.2 in carp- A. mola polyculture ponds. The $\mathrm{pH}$ reading in treatments of present experiment is more or less similar to Kohinoor (1998). Total alkalinity ranged from 76.0 and 150.0 $\mathrm{mg} \mathrm{L}^{-1}$ in this experiment. Moyle (1946) stated that water bodies having total alkalinity more than $200.0 \mathrm{mg} \mathrm{L}^{-1}$ were highly productive. Bhowmic and Tripathi (1985) recorded the total alkalinity from 91.4 to $92.6 \mathrm{mg} \mathrm{L}^{-1}$ in research experiment's ponds of India. The total alkalinity record at present seems to be similar with the finding of Bhowmic and Tripathi (1985). Free $\mathrm{CO}_{2}$ of pond water ranged from $10.5 \mathrm{mg} \mathrm{L}^{-1}$ to $16.4 \mathrm{mg} \mathrm{L}^{-1}$ during experimental period and it did not vary among the treatments. The upper limit of free carbon dioxide has been recommended as $25 \mathrm{mg} \mathrm{L}^{-1}$ for the safeguard of fish culture (Hynes, 1970). Present finding of free $\mathrm{CO}_{2}$ seems to be suitable for fish culture according to (Hynes, 1970).

\section{CONCLUSION}

It was concluded from the present study that A.mola does not compete for food with silver carp $(H$. molitrix), bighead carp (A. nobilis), rohu (L. rohita) and naini (C. mrigala) combination but it showed adverse effect in the growth and production of silver carp, bighead carp, rohu, naini in combination of grass carp and common carp. so A.mola can be cultured successfully in semi intensive carp polyculture system in Nepalese condition to improve the economic and malnutrition condition of rural poor fish farmers and fishermen.

\section{ACKNOWLEDGEMENTS}

Authors are grateful to Mr. Bijaya Kumar Mallik Ex. Director General, Department of Agriculture, Govt. of Nepal, and Chief of staff Fish farm (Government of Nepal) Mr. Ravi Lal Sharma. This work was financed with a grant from UGC Nepal for the promotion of research work in Nepal.

\section{REFERENCES}

Alim, M. A.; Wahab, M. A. and Milstein, A. (2005). Effects of increasing by $20 \%$ the stocking density of large carps of the basic "cash" carp - small fish polyculture of Bangladesh. Aquaculture Research, 36: 317325.

Banerjea, S. M. (1967). Water quality and soil condition of fish ponds in some states of India in relation to fish production. Indian $J$. Fish., 14 (1 \& 2): 115-144.

Bhowmic, M. I. and Tripathi, S. D. (1985). The plankton and fish growth of ponds under semi intensive fish culture in acid soils of Jalpaiguri, West Bengal. Journal of the Inland Fisheries Society of India, 17 (1\&2): 39-47.

Boyd, C. E. (1979). Water Quality in Warm water Fish Ponds. Auborn University, Craftmaster Printers, Opelika, Alabama.U.S.A.

Da Silva, L. B.; Barcellos, L. J.; Quevedo, R. M.; De Souza, S. M. J.; Kreutz, L. C.; Ritter, F. et al. (2006). Alternative species for traditional carp polyculture in southern South America: Initial growing period. Aquaculture, 255: 417-428.

Environment Statistics of Nepal (2013). Government of Nepal, National Planning Commission Secretariat, Central Bureau of Statistics, Thapathali, Kathmandu, Nepal.

FAO (2014). Fisheries and aquaculture country profiles, National aquaculture sector overview Nepal. FAO Fish Stat J-Universal software for fishery statistical time series. Food and Agriculture organization of the United Nations, Rome, Italy.

Felts, R. A.; Rajts, F. and Akhteruzzaman, M. (1996). Small Indigenous Fish Species Culture in Bangladesh (Technical Brief). 
IFADEP Sub Project 2, Development of Inland Fisheries. pp. 41.

Gurung, T. B.; Bista, J. D.; Wagle, S. K. and Sah, S. (2003). Aquatic biodiversity in the himalayan kingdom Nepal. Paper presented in the Himlayan Biodiveristy Conservation Symposium organized in Kathamandu, Nepal.

Hossain, M. A. and Afroze, S. (1991). Small fishes as a resource in rural Bangladesh. Fish Byte., 9: $16-18$.

Hossain, M. Y.; Ahmed, Z. F.; Leunda, P. M.; Islam, A. K. M. R.; Jasmine, S.; Oscoz, J. et al. (2006). Length-weight and length-length relationships of some small indigenous fish species from the Mathabhanga River, southwestern Bangladesh. Journal of Applied Ichthyology, 22: 301- 303.

Hynes, H. B. N. (1970). The ecology of running waters Univ. Toronto Press, Toronto. pp. 555.

Kadir, A.; Wahab, M. A.; Milstein, A.; Hossain, M. A.; Seraji, M. T. I. (2007). Effects of silver carp and the small indigenous fish mola Amblypharyngodon mola and punti Puntius sophore on fish polyculture production. Aquaculture, 273 (4): 520-531.

Kohinoor, A. H. M.; Wahab, M. A. and Thilsted, S. H. (1998). Polyculture of carp with mola (Amblypharyngodon mola), chela (Chela cachius) and punti (Puntius sophore) under semi intensive system. The Fifth Asian Fisheries Forum, held on November 11-14 in Chiang Mai, Thailand.

Kohinoor, A. H. M. and Wahab, M. A. (1998). Studies on the production performances of small indigenous fish species in Bangladesh. Proceedings of National Workshop on FoodBased Strategies for Improving Nutrition in Bangladesh, 17-28. Dhakar, Bangladesh.

Kohinoor, A. H. M. (2000). Development of culture technology of three small indigenous fish mola (Amblypharyngodon mola), punti (Puntius sophore) and chela (Chela cachius) with notes on some aspects of their biology. $\mathrm{Ph}$. D. Thesis, Department of Fisheries Management, Bangladesh Agricultural University, Mymensingh. Bangladesh.

Kunda, M.; Azim, M. E.; Wahab, M. A.; Dewan, S.; Roos, N. and Thilsted, S. H. (2008). Potential of mixed culture of freshwater prawn (Macrobrachium rosenbergii) and self-recruiting small species mola (Amblypharyngodon mola) in rotational ricefish/prawnculture systems in Bangladesh. Aquaculture Research, XX: 1-12.

Lakshmanan, M. A. V.; Sukumaran, K. K.; Murty, D. S.; Chakraborty, D. P. and Philipose, M. T. (1971). Preliminary observations on intensive fish farming in freshwater ponds by the composite culture of Indian and exotic species. J. Inland Fish. Soc. India, 3: 1 -21.

Mazid, M. A.; Zaher, M.; Begum, N. N.; Ali, M. Z. and Nahar, F. (1997). Formulation of cost effective feeds from locally available ingredients for carp polyculture system for increased production. Aquaculture, 151: 7178.

Miah, M. J. U. and Siddique, W. H. (1992). Studies on the food and feeding habits of Mola, Amblypharyngodon mola. Bangladesh Journal of Agricultural Science, 19 (2): 165170.

Milstein, A. (1992). Ecological aspects of fish species interactions in polyculture ponds. Hydrobiology, 231: 17-186.

Moyle, J. B. (1946). Some chemical factors influencing the distribution of aquatic plants in Minnesota. Amer. Midi. NaH; 34: 402426.

M. O. P. H. (2014). Annual report, Department of Health Services, Government of Nepal, Teku, Kathmandu. pp. 20-38.

Ophenheimer, J. R.; Ahmed, M. G.; Huque, A.; Haque, K. A.; Alam, A. K. M. A.; Aziz, K. M. et al. (1978). Limnological studies of three ponds in Dhaka, Bangladesh. Bangladesh J. Fish, 1 (1): 10- 28.

Paul, S. (1998). Comparison between carp polyculture system with silver carp (Hypophthalmichthys molitrix) and with small indigenous fish mola (Amblypharyngodon mola). M. S. dissertation, Department of Fisheries Management, Bangladesh Agricultural University, Mymensingh. pp. 85 .

Rahman, M. M. (2006). Food web interactions and nutrient dynamics in polyculture ponds. (Doctoral dissertation, Wageningen University), Netherland.

Rai, A. K.; Clausen, J. and Smith, S. F. (2008). Potential development interventions for fisheries and aquaculture development in Nepal. Food and agriculture organization of 
the United Nations Regional office for Asia and the Pacific Bangkok. Asia Pacific Fishery Commission Ad hoc Publication.

Roy, N. C. (2004). Effects of Carp-SIS Polyculture System on Pond Fish Production, Nutritional Security and Socioeconomic Benefit of the Rural People, Ph. D. Dissertation, Department of Fisheries Management, Bangladesh Agricultural University, Mymensingh. pp. 184.

Stirling H. P. (1985). Chemical and Biological Methods of Water Analysis for Aquaculturists. Institute of Aquaculture, University of Stirling, Scotland, UK.

Swingle, H. S. (1967). Standardization of chemical analyses for waters and pond muds. $F A O$ Fish. Rep., 4 (44): 397-421.
Wahab, M. A.; Ahmed, Z. F.; Islam, M. A.; Haq, M. S. and Ramatullah, S. M. (1995). Effects of introduction common carp, Cyprinus carpio (L.) on pond ecology and growth of fish in polyculture. Aquaculture Research, 26: 619-628.

Wahab, M. A.; Aziz, M. E.; Haque, M. M. and Ahmed, Z. F. (1996). Effects of frequency of fertilization on water quality and fish yields Progress. Agric., 7 (2): 33-39.

Wahab, M. A.; Rahman, M. M. and Milstein, A. (2002). The effect of common carp, Cyprinus carpio (L.) and Mrigal, Cirrhinus mrigala (Hamilton) as bottom feeders in major carp polycultures. Aquaculture Research, 33:547556. 